\title{
Integrated assessment of nonpoint source pollution of a drinking water reservoir in a typical acid rain region
}

\author{
L. Chen · R. M. Liu $\cdot$ Q. Huang $\cdot$ Y. X. Chen • \\ S. H. Gao $\cdot$ C. C. Sun $\cdot$ Z. Y. Shen
}

Received: 8 October 2011/Revised: 9 January 2012/Accepted: 7 May 2012/Published online: 17 April 2013

(C) Islamic Azad University (IAU) 2013

\begin{abstract}
Nonpoint source pollution generated by agricultural production and city construction has been studied for decades, but very few researches have been conducted on the regional assessment of nonpoint source pollution in the acid rain regions, particularly relating to the control of pollutant in the drinking water source areas. In this study, an integrated framework was applied to estimate nitrogen and phosphorous load in a typical acid rain influenced reservoir, China. The method comprised three separate steps: (1) a watershed model—soil and water assessment tools-was used to estimate nitrogen and phosphorous load from the upper stream watershed; (2) collection of acid rain samples, together with a GIS-based calculation to estimate the atmospheric deposition flux; (3) introduction of a simple export coefficient method. The case study indicated atmospheric deposition accounted for $56.75 \%$ of total nitrogen load during the year, with the highest level of deposition load taking place during the wet season. Maximum phosphorous $(93.37 \%)$ was linked to the upstream runoff, originating from the upper watershed. Further analysis by watershed model and export coefficient method indicated forest exported most total nitrogen $(27.72 \%)$ and total phosphorous $(58.78 \%)$ in the upstream watershed. Results indicated that in the region influenced by acid rain, the nitrogen management should encompass the management of land use practices and the control of acid rain in catchments feeding into drinking water storage areas. It could be inferred that NOX emissions might cause both
\end{abstract}

L. Chen · R. M. Liu $(\bowtie) \cdot$ Q. Huang · Y. X. Chen ·

S. H. Gao - C. C. Sun - Z. Y. Shen

State Key Laboratory of Water Environment Simulation,

School of Environment, Beijing Normal University,

Beijing 100875, China

e-mail: liurm@bnu.edu.cn globe warming and eutrophication in the drinking water sources. This paper could provide a basis for water quality management in such regions.

Keywords Acid rain - Drinking water source $\cdot$ Export coefficient method · GIS · Nonpoint source pollution · Soil and water assessment tool

\section{Introduction}

The growing level of pollution and economic growth in the past decades have imposed increasing threat to the drinking water sources worldwide (USEPA 2002, 2006; World Bank 2009; Jiang et al. 2011), which necessitates a rapid conversion of watershed modeling into sound management practices (Kho et al. 2009; Meng 2009). The science-based protection of drinking water focuses on identifying various sources of pollution (Canale and Effler 1989; Trauth and Xanthopoulos 1997; Edwards and Withers 2008; Karbassi et al. 2011). Nowadays, nonpoint source (NPS) pollution has been already identified as the most significant anthropogenic sources of drinking water pollution (Igbinosa and Okoh 2009; Markus et al. 2010).

In general, NPS pollution could be categorized into municipal wastewater, storm water runoff, agricultural drainage, and atmospheric deposition (Todd et al. 1989). Recent studies have focused on the fate and transport of NPS pollution from upstream watershed into the receiving water (Hallberg and Keeney 1993; Livingston and Cory 1998; Ghaffari et al. 2010; Tu and Xia 2008). It has been indicated that a high correlation between agricultural activities and NPS exists, especially in the areas of poverty where people depend heavily on agriculture (Markus et al. 2010). This type of NPS pollution often represents as a 
mount of nitrogen $(\mathrm{N})$ and phosphorous $(\mathrm{P})$ pollution leaching into drinking water reservoirs, particularly from fertilizers and various carcinogenic substances found in pesticides (Jury and Nielsen 1989; Ling and El-Kadi 1998). In the regions with sandy soils, the extensive use of fertilizers is now considered as the main source of NPS pollution (Hubbard and Sheridan 1994; Paul and Zebarth 1997; Harter et al. 2002). The movement of NPS-N and NPS-P from rural areas and animal wastes can be of serious concern in high density of dairy farm areas (Carey 2002). It is also found that elevated nitrate concentration in groundwater is widespread found around dairy, barnyard, and feedlots.

Acid rain has recently attracted a lot of attention due to the dramatic increase with the use of fertilizers and fossil fuels (Huang et al. 2010). The mixture of wet and dry deposition from the acid atmosphere would result in a high pollution level in the receiving area. The Integrated Atmospheric Deposition Network (IADN) is developed in USA to monitor atmospheric $\mathrm{N}$ and $\mathrm{P}$ deposition. In Europe and North America, it is reported that inorganic $\mathrm{N}$ deposition is in the ranges of $1-75$ and $3-32 \mathrm{~kg} /$ (ha year), respectively (Holland et al. 1999; Nadelhoffer 2001). The acid deposition is also found as a major environmental problem in China. In the Guanzhong Plain of Shanxi province, a region of intensive agriculture in North China, the averaged $\mathrm{N}$ deposition is $16.3 \mathrm{~kg} /$ (ha year) comprising $80 \%$ NH4-N ( $\mathrm{Li}$ and $\mathrm{Li}$ 1999). In the Jiulong watershed, East China, the $\mathrm{N}$ deposition is estimated to be $2.20 \pm 1.69 \mathrm{mg} / \mathrm{l}$ (Chen et al. 2008).

Sichuan province in Southwest China is another major region of acid deposition, where $\mathrm{N}$ deposition is even higher than that of East China. It is thus, theoretically clear that the NPS-N input in the regions controlled by acid rain is also likely to originate from atmospheric deposition, as well as agricultural activity and rural pollution. However, there are few systemic studies on the diverse sources of NPS and the impact of NPS on drinking water resources has not been clearly demonstrated in such regions.

An accompanying concern focuses on developing the techniques needed to quantify the diverse sources of NPS pollution. Although many studies have focused on this issue, regional assessment is still complicated by the fact that the sources of NPS-N and NPS-P input are spatially distributed throughout watersheds (Ernst and Owens 2009). In fact, atmospheric deposition is often estimated by means of rain sampling (Holland et al. 1999; Nadelhoffer 2001; Chen et al. 2008). However, NPS pollution from upper watershed is not commonly measured due to a lack of knowledge of the spatial heterogeneity of watersheds as well as the high costs associated with such monitoring (Abbott et al. 1986; Nandakumar and Mein 1997). Watershed models are designed and utilized to estimate the spatially and temporally distribution of NPS-N and NPS-P (Singh and Frevert 2002; Bowes et al. 2005). These models include Soil and Water Assessment Tool (SWAT) (Arnold et al. 1993; Gassman et al. 2007), Simulator for Water Resources in Rural Basins (SWRRB) (Esen and Uslu 2008; Williams et al. 1985), Areal Nonpoint Source Watershed Environment Response Simulation (ANSWERS) (Beasley et al. 1980; Singh et al. 2006), Hydrologic Simulation Program-Fortran (HSPF) (Bicknell et al. 2001; Ribarova et al. 2008), Agricultural NonPoint Source Pollution Model (AGNPS) (Cho et al. 2008; Young et al. 1989) and Assessment Science Integrating Point and Nonpoint Sources (BASINS) (Whittemore 1998). However, these models are often complex and characterized by a multitude of parameters (Ding et al. 2010), which hinders the application in watershed modeling to some extent (Singh et al. 2005).

In contrast, there are some studies providing simple, efficient, and empirical methods to estimate NPS load. These methods are the Agricultural Pollution Potential Index (APPI) (Petersen et al. 1991), the phosphorus Index (PI) (Birr 2001; Gburek et al. 2000; Lemunyon and Gilbert 1993), the Phosphorus Ranking Scheme (PRS) (Magette 1993), the flow analysis (SFA) (Chen et al. 2010), and the Export Coefficient Model (ECM) (Omernik 1976). These methods are often simple and have no need for spatial and complex input. Nevertheless, the behavior of NPS pollution in the soil and in runoff is complex, so these empirical methods are often inadequate in terms of detailed dynamic simulation.

The Baixi reservoir is the largest hydropower dam in Ninghai county and main drinking water supply for the city of Ningbo, Zhejiang Province, China. This facility comprises the dam, the hydropower station, the flood spillway, and a number of weirs. Nowadays, the Baixi reservoir plays an important role in local flood control, power generation, navigation, as well as supplying drinking water. In spite of protection measures have been taken since 2006, the concentration of $\mathrm{N}$ periodically exceeds the permitted environmental standard, particularly after heavy rain. One critical cause for public concern is reported that the Baixi reservoir locates in one of the three most serious acid rain regions in China. Therefore, it is believed that excessive atmosphere deposition would cause a wide range of problems such as eutrophication, toxic algal blooms, oxygen depletion and loss of biodiversity to drinking water supplies. Therefore, it is important to identify various sources of NPS-N and NPS-P sources to the Baixi reservoir.

This paper has two objectives: (1) to identify the sources of NPS-N and NPS-P input in a typical acid rain influenced region; (2) to develop a framework to combine different methods for assessing NPS-N and NPS-P sources accurately. In this study, the sources of NPS-N and NPS-P were 
divided into three categories: (1) upper watershed pollution resulting from certain land use; (2) atmospheric acid deposition; (3) other internal inputs such as rural and tourism pollution. The corresponding method framework used for NPS load identification encompasses: (1) a watershed SWAT model was used to estimate NPS-N and NPS-P in the 254- $\mathrm{km}^{2}$ upstream watershed area; (2) atmospheric deposition was calculated based on acid rain sampling and a GIS-related method; (3) a simple ECM was also introduced to determine pollution level in rural areas and pollution due to tourism. The description of study area and related method could be found in the next section.

\section{Materials and methods}

\section{Site description}

In this study, Baixi watershed was selected to demonstrate the NPS sources and to develop the corresponding modeling framework. This reservoir is a major hydraulic facility in the eastern region of Zhejiang Province, China (Fig. 1). The upstream watershed encompassed the upper catchments of three rivers-Dasong River, Hunshui River and Qingshui River-draining an area of $254 \mathrm{~km}^{2}$. A humid northern-subtropical-monsoon climate covered this area, with the following characteristic features: distinct seasons with adequate illumination and abundant precipitation; an annual mean temperature of $16.1{ }^{\circ} \mathrm{C}$ (from $9.6^{\circ} \mathrm{C}$ to $39.7^{\circ} \mathrm{C}$ ) and an annual mean precipitation of $1,091.2 \mathrm{~mm}$. The reservoir is located in a mountainous area with vegetation comprising agricultural crops, secondary forest and product forest. The land-uses in the watershed included $7 \%$ cropland, $91 \%$ forest, and $2 \%$ barren land. In addition, zonal yellow soil (33\%) and skeleton soil (35\%) were dominant in the watershed followed by $12 \%$ red soil, $19 \%$ yellow-red soil, and $0.2 \%$ paddy soil.

Construction of the Baixi reservoir started in 1997. From 2002 onwards, the reservoir had functioned as a facility for the storage and supply of drinking water to millions of people in Ningbo City. According to the site investigation of 2009 and 2010, there were no industries and few large villages in the Baixi watershed. Daily gauged data of stream flow were collected from the Ningbo hydrology station and monthly measured data of water quality were obtained from Ninghai county station. These data, which represented the values of these parameters in upstream outlets of the reservoir, were used to calibrate and validate the SWAT model.

\section{SWAT model}

The watershed SWAT model is a physically based, continuously distributed model operated on a daily time step, which has been applied in many countries, including Finland (Francos et al. 2003), Germany (Weber et al. 2001), U.S. (Santhi et al. 2006), India (Behera and Panda 2006), France (Plus et al. 2006), and China (Yang et al. 2007). These studies indicated that SWAT performed well in NPS simulation. In this study, SWAT was used for upstream watershed modeling. Detailed information pertaining to the model is shown in Table 1.

Many studies have indicated that monthly based SWAT simulation generally provides better results than daily based simulation (Shen et al. 2008). Monthly based data were, therefore, adopted for calibration and validation. Calibration of stream flow was undertaken from January 2005 to December 2006, and validation from January 2007 to December 2008. As only a few monthly water quality data were available for the study region, so only parameters related to ammonia (NH3) and TP modeling were calibrated and validated. The Nash-Sutcliffe efficiency coefficient $\left(E_{\mathrm{NS}}\right)$ was set to assess the degree of fit between observed data and SWAT outputs (Nash and Sutcliffe 1970).

$E_{\mathrm{NS}}=1-\frac{\sum_{i=1}^{n}\left(Q_{\mathrm{sim}, i}-Q_{\mathrm{mea}, i}\right)^{2}}{\sum_{i=1}^{n}\left(Q_{\mathrm{mea}, i}-\bar{Q}_{\mathrm{mea}}\right)^{2}}$

where, $Q_{\text {mea }, i}$ is the observed data, $Q_{\text {sim }, i}$ is the simulated data, $\bar{Q}_{\text {mea }}$ is the mean value of the observed data, and $n$ is the simulation time.

The atmospheric deposition method

Atmospheric deposition flux originates from two sources: (1) a component that falls directly on the surface of the Baixi reservoir, (2) an upstream catchment component that enters the reservoir indirectly via runoff. In this study, indirect flux was considered in a SWAT simulation by changing the initial concentration of $\mathrm{N}$ and $\mathrm{P}$ in the code of SWAT model. Atmospheric deposition in this context only related to the component that fell directly falling onto the surface of the Baixi reservoir. In this study, a three-step procedure was encompassed as described below.

1. Atmospheric flux was estimated by means of periodic rain sampling. Rain sample data from 2005 to 2006 was collected from local environmental protection bureau (Table 2) and a further sampling was conducted in the median rainfall season (April, 2010), the wet season (July and August, 2010) after major rainfall events in the Baixi watershed. The sampling spots were chosen adjacent to the reservoir. The rain samples were analyzed using state standard analytical methods, using the alkaline potassium per sulfate oxidation-UV spectra photo metric method and the 
Fig. 1 Location of Baixi reservoir

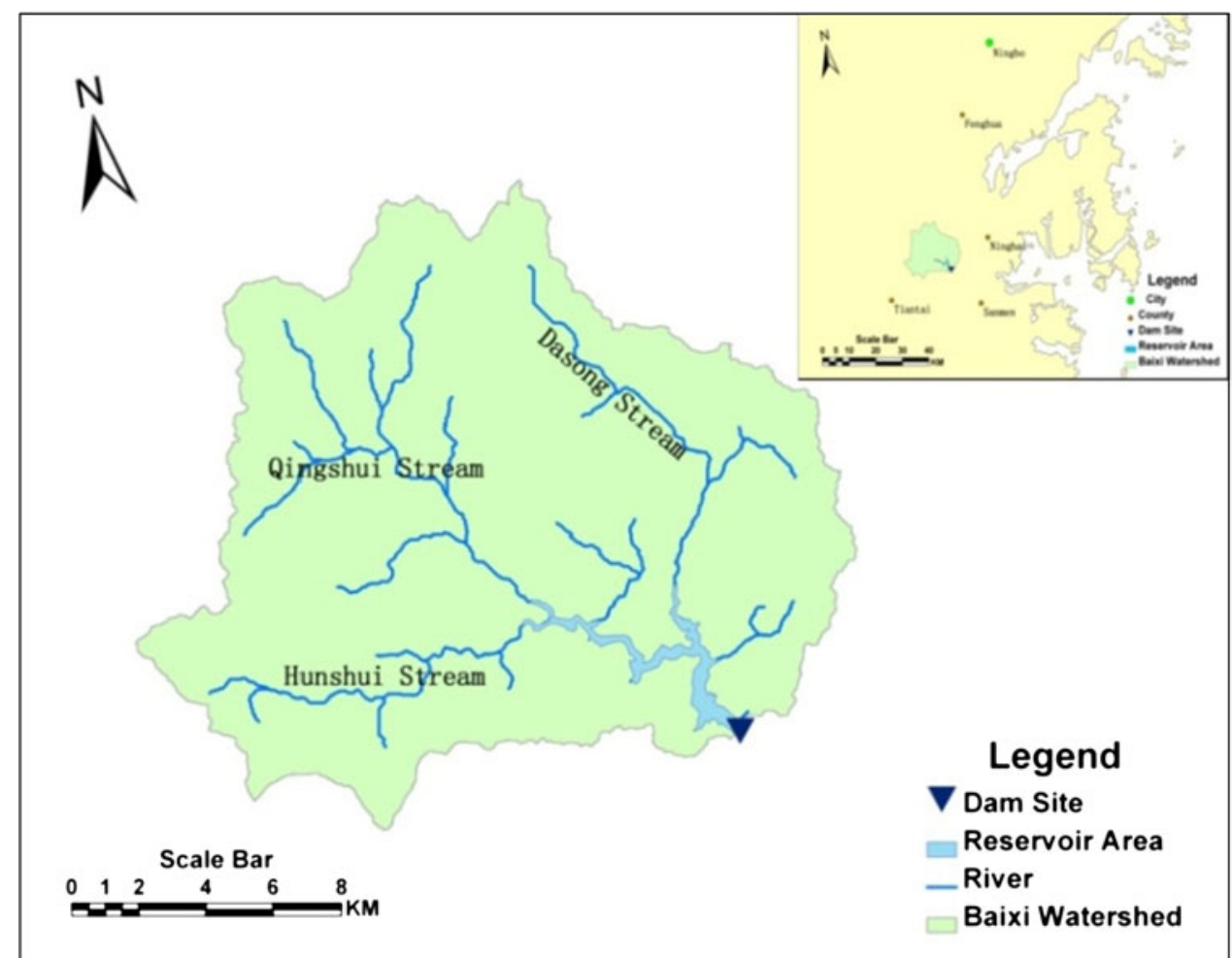

Table 1 The data sources for SWAT model

\begin{tabular}{|c|c|c|}
\hline Data type & Scale & Sources \\
\hline DEM map & $1: 50,000$ & $\begin{array}{l}\text { National Aeronautics and } \\
\text { Space Administration (NASA) } \\
\text { (released in June, 2009) }\end{array}$ \\
\hline Soil type map & $1: 1,000,000$ & $\begin{array}{l}\text { Chinese Academy of Sciences of } \\
\text { the soil }\end{array}$ \\
\hline Land use map & $1: 100,000$ & $\begin{array}{l}\text { Remote sensing image } \\
\text { interpretation from } 2007\end{array}$ \\
\hline Meteorological & & National Meteorological Center \\
\hline $\begin{array}{l}\text { Hydrological } \\
\text { water }\end{array}$ & & $\begin{array}{l}\text { Baixi Reservoir Administration } \\
\text { Bureau }\end{array}$ \\
\hline $\begin{array}{l}\text { Crop } \\
\text { management } \\
\text { practices }\end{array}$ & & Field research \\
\hline $\begin{array}{l}\text { Socio-economic } \\
\text { data }\end{array}$ & & Yearbook of the local regions \\
\hline
\end{tabular}

ammonium-molybdate spectrophotometric method for assessing concentrations of $\mathrm{TN}$ and $\mathrm{TP}$, respectively.

2. Daily rainfall data from 2005 to 2010 was collected at eight rainfall gauges in the watershed and was interpolated to generate a rainfall data layer for the reservoir surface. The Thiessen Polygon method (Chaubey et al. 1999) was used for the spatial interpolation of rainfall data by means of Geographic Information System
Table 2 The sampling result from 2005 to 2010

\begin{tabular}{llllll}
\hline Year & Month & Sample number & PH & TN & TP \\
\hline 2005 & 7 & 2 & 4.75 & 0.96 & \\
& 8 & 1 & 5.25 & 0.51 & \\
& 11 & 3 & 4.14 & 0.95 & \\
& 1 & 2 & 4.06 & 2.80 & \\
& 2 & 1 & 4.08 & 0.95 & \\
2006 & 5 & 2 & 4.25 & 0.47 & \\
& 6 & 4 & 4.57 & 1.4 & \\
& 7 & 1 & 4.56 & 0.62 & \\
& 4 & 2 & 5.43 & 1.12 & 0.010 \\
& 7 & 1 & 4.18 & 1.44 & 0.014 \\
& 8 & 2 & 5.5 & 0.43 & 0.014 \\
\hline
\end{tabular}

(Arcview Version 3.2a). This method is based on the weightings, calculated by means of ratios of the areas of catchment controlled by each rainfall gauging station as illustrated in Fig. 2. The spatial interpolation of rainfall data was determined using the Thiessen Polygon method of ArcGIS spatial analysis tool, as described in the equation below:

$\bar{P}=\frac{P_{1} F_{1}+P_{2} F_{2}+\ldots+P_{n} F_{n}}{F}=\sum_{i=1}^{n} P_{i} \frac{F_{i}}{F}$

where, $P_{i}$ represents rainfall data at Station $\mathrm{I}$, and $F_{i}$ is the Thiessen polygon area associated with Station I. 
Fig. 2 Location of rain stations

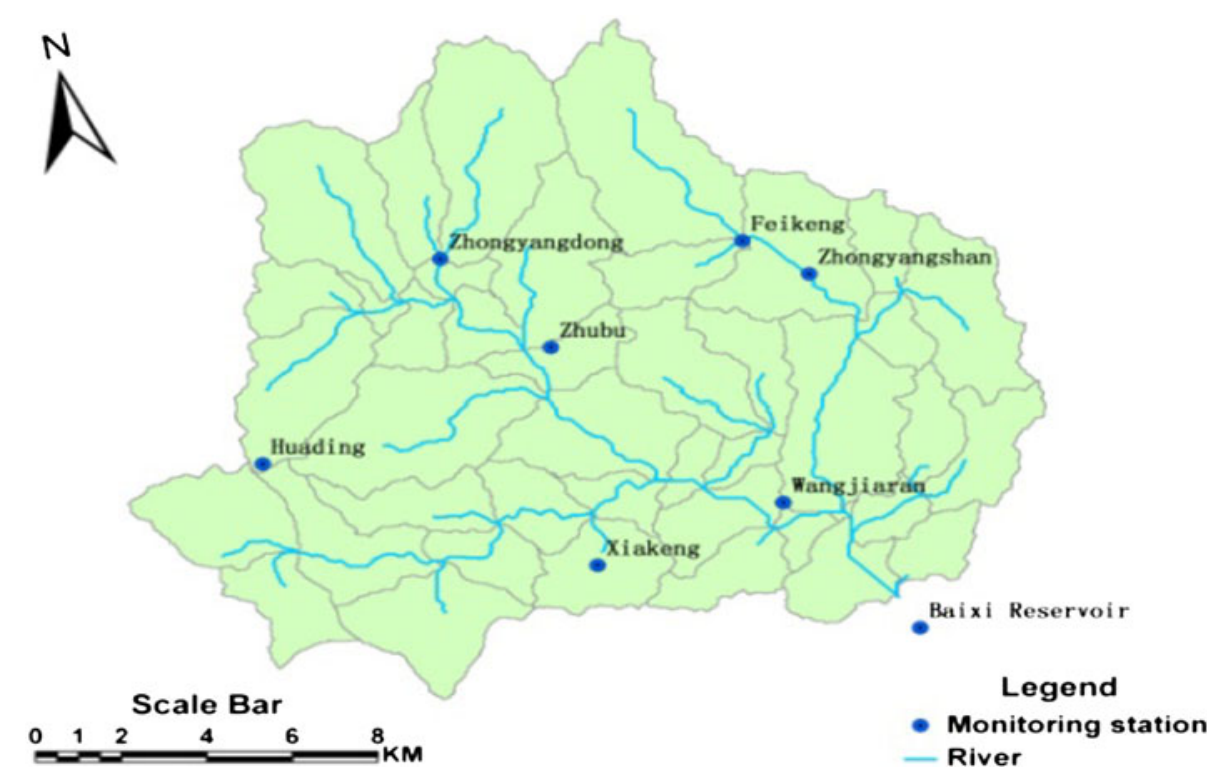

3. Atmospheric deposition was computed by multiplying total precipitation and the pollutant concentration in the rain samples. Total precipitation was estimated using the variable surface area of the reservoir and the precipitation depth data determined by spatial interpolation. Dry deposition was not considered directly, because of the high rainfall characteristics of the climate and the limited equipment. Nevertheless, according to Chen et al. (2008), dry deposition comprised $34 \%$ of total $\mathrm{N}$ deposition in a neighborhood watershed, which was also reported to locate in the same acid rain region. Total $\mathrm{N}$ flux from atmospheric deposition was, thus, determined by multiplying 1.5 and the wet deposition flux.

\section{The ECM method}

In the Baixi watershed, the inherent sources from the upper watershed could not be commonly modeled due to a lack of knowledge of the spatial heterogeneity of small villages and tourist spots as well as the high costs associated with such investigation. Instead of SWAT simulation, it necessitated a combination of ECM to assess the sources of NPS-N and NPS-P pollution. The proportion of NPS pollution from upstream rural and tourism areas was calculated by means of the ECM, which is based on the assumption that the $\mathrm{N}$ and $\mathrm{P}$ loads exported from a watershed equal the sum of the losses from individual sources (from land use, livestock, rural populations and atmospheric deposition). The model allowed an whole estimation and analysis of nutrient pollutants (Johnes 1996). The ECM is determined as follows:

$L=\sum_{i=1}^{n} E_{i}\left[A_{i}\left(I_{i}\right)\right]+p$

where $L=$ loss of nutrients $(\mathrm{kg}), E_{i}=$ export coefficient for nutrient source $i$ (kg/ca year or $\mathrm{kg} / \mathrm{km}^{2}$ year), $A_{i}=$ catchment area associated with a particular land use type $i\left(\mathrm{~km}^{2}\right)$, or number of livestock type $i$, or of the human population, where $I_{i}$ is the input of nutrients from source $i(\mathrm{~kg})$, and $p$ is the input of nutrients from precipitation $(\mathrm{kg})$.

Based on the site investigation of 2010, there were 29 villages and 7 tourism spots in the Baixi watershed (Fig. 3). Detailed information of pollutants produced by rural human population and from animals was summarized in Table 3. Calculations of rural nutrient input as well as that due to tourism were based on the rural population, poultry, and tourism data collected from local government. As seen in Fig. 3, the villages in Baixi watershed are mainly located in upstream areas, while the tourism spots are concentrated around the Dasong River. In the Baixi watershed, composted toilets were built near farmhouses and resultant manure was collected and carried to a compositing mill outside the watershed. However, there was no integrated drainage and water treatment system in the Baixi watershed, and wastewater from rural villages and cow barns were flushed directly into the river by overland runoff. Based on a local administration investigation in 2010, the development of accommodation and restaurants was not permitted in the Baixi drinking water reservoir area, and garbage and feces packed and disposed of beyond the Baixi watershed, as described above. Hence, the pollution due to tourism was mainly caused by wastewater produced by the participants in the present study. Thus, 
rural and tourism-related pollution was calculated by means of ECM.

\section{Results and discussion}

Land-use load estimation

\section{Calibration and validation}

As shown in Fig. 4 (for runoff) the ENS during the calibration period and validation periods was 0.79 and 0.84 , respectively, and 0.66 and 0.54 for NH3 and TP, respectively. Compared to other SWAT applications (Gassman et al. 2007), the value of the ENS was, thus, concluded that the SWAT model was capable of modeling NPS pollution in the Baixi Watershed.

\section{Temporal distribution}

As shown in Fig. 5, TN load in the upstream watershed varied between 160.47 and 186.22 t. The TN load was greatest in 2008, followed by 2006; the lowest TN load was observed in 2007. Levels of TN were, however, stable and no obvious trend was observed from 2005 to 2009. A declining trend $(2006>2005>2007>2008>2009)$ was noted for TP indicated by levels of $6.12 \mathrm{t}$ in 2005 , which declined to $2.18 \mathrm{t}$ in 2009 . This could be due to the development of local forest planting and to stringent rural pollution management in the Baixi watershed from 2006 onwards.

Monthly TN and TP, summarized in Fig. 5, indicate several peak values for both TN and TP, which suggest that there may be no clear relationship between rainfall and upstream NPS input. Previous studies were based on the assumption that NPS pollution was dominated by precipitation (Hallberg and Keeney 1993; Shen et al. 2008; Ghaffari et al. 2010). Results in this paper, however, challenge this assumption. In Baixi watershed, the peak TN and TP input from upstream occurred in March and April, when rainfall was not intense. This can be explained by high levels of agricultural and forest activities in the Baixi watershed during these 2 months: damage to the upper soil due to plowing, a high application of organic fertilizers, activities that result in soil erosion and NPS export, respectively. During the wet season (July, August and September), the accumulated flow volume amounted to $30.77 \%$ of annual flow. During high rainfall season, the concentrations of $\mathrm{TN}$ and $\mathrm{TP}$ were 14.53 and $29.99 \%$, respectively. During the flood season, heavy flushing also resulted in an increase in $\mathrm{TN}$ and $\mathrm{TP}$ load from upstream areas as the flow increased. The second growing season for rice during August also resulted in higher leaching of organic $\mathrm{N}$ and $\mathrm{P}$ after fertilizer application. The levels of both $\mathrm{N}$ and $\mathrm{P}$ decreased during September, due to less rainfall and anthropogenic activities, but began to increase
Fig. 3 Location of village and tourism spots

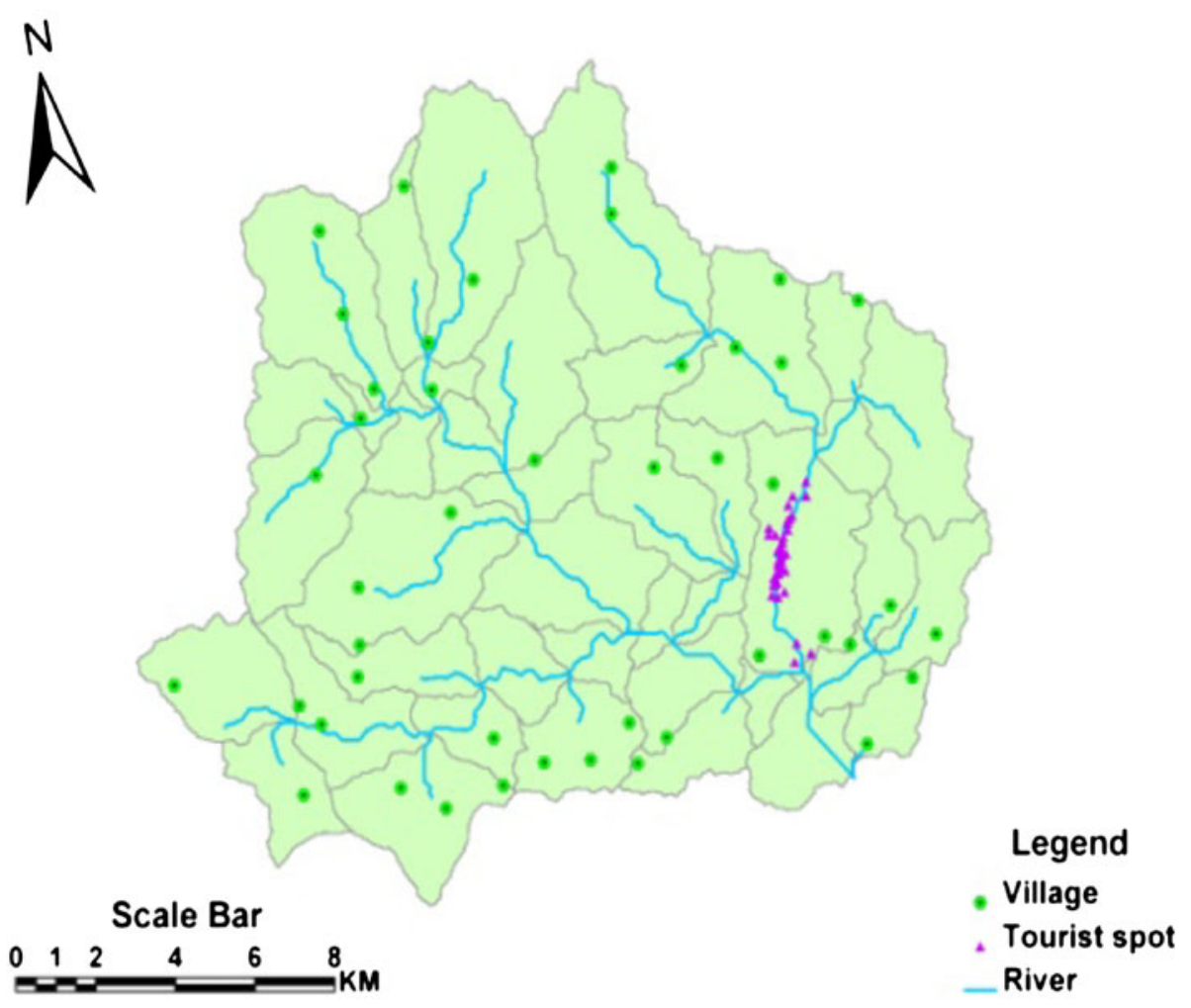


Table 3 Rural and livestock pollution

\begin{tabular}{lllll}
\hline Pollutant name & \multicolumn{2}{l}{ Contamination index } & & TN \\
\cline { 2 - 5 } & \multicolumn{1}{l}{ Total } & BOD5 & & TP \\
\hline Pollutions serves as the agricultural fat & & & \\
Domestic sewage & $801 / \mathrm{p} \mathrm{d}$ & $70-120 \mathrm{mg} / \mathrm{l}$ mean value is $100^{\mathrm{a}}$ & $20-30 \mathrm{mg} / \mathrm{l}$ mean value is 25 & $7-15 \mathrm{mg} / \mathrm{l} \mathrm{mean} \mathrm{value} \mathrm{is} 10$ \\
Human excrement & $0.8 \mathrm{~kg} / \mathrm{p} \mathrm{d}$ & $0.009 \mathrm{~kg} / \mathrm{p} \mathrm{d}$ & $0.004 \mathrm{~kg} / \mathrm{p} \mathrm{d}$ & $0.001 \mathrm{~kg} / \mathrm{p} \mathrm{d}$ \\
Cattle excrement & $21 \mathrm{~kg} / \mathrm{h} \mathrm{d}$ & $0.52 \mathrm{~kg} / \mathrm{h} \mathrm{d}$ & $0.2 \mathrm{~kg} / \mathrm{h} \mathrm{d}$ & $0.04 \mathrm{~kg} / \mathrm{h} \mathrm{d}$ \\
Pig excrement & $5.8 \mathrm{~kg} / \mathrm{h} \mathrm{d}$ & $0.37 \mathrm{~kg} / \mathrm{h} \mathrm{d}$ & $0.027 \mathrm{~kg} / \mathrm{h} \mathrm{d}$ & $0.006 \mathrm{~kg} / \mathrm{h} \mathrm{d}$ \\
Sheep excrement & $2.9 \mathrm{~kg} / \mathrm{h} \mathrm{d}$ & $0.07 \mathrm{~kg} / \mathrm{h} \mathrm{d}$ & $0.03 \mathrm{~kg} / \mathrm{h} \mathrm{d}$ & $0.006 \mathrm{~kg} / \mathrm{h} \mathrm{d}$ \\
Domesticated fowl excrement & $0.12 \mathrm{~kg} / \mathrm{h} \mathrm{d}$ & $0.008 \mathrm{~kg} / \mathrm{h} \mathrm{d}$ & $0.002 \mathrm{~kg} / \mathrm{h} \mathrm{d}$ & $0.0008 \mathrm{~kg} / \mathrm{h} \mathrm{d}$ \\
Lives organic trash & $0.2 \mathrm{~kg} / \mathrm{p} \mathrm{d}$ & $0.1 \mathrm{~kg} / \mathrm{kg}$ & $0.2 \mathrm{~kg} / \mathrm{kg}$ & $0.08 \mathrm{~kg} / \mathrm{kg}$
\end{tabular}

$1 / \mathrm{p} \mathrm{d}$ is the liter of each person of daily, $\mathrm{kg} / \mathrm{p} \mathrm{d}$ is a kilogram of each person daily, $\mathrm{kg} / \mathrm{h} \mathrm{d}$ is a kilogram of each head daily

${ }^{\mathrm{a}}$ The low BOD5 density is a result of excrement and dining residual and so on were used as fertilizer
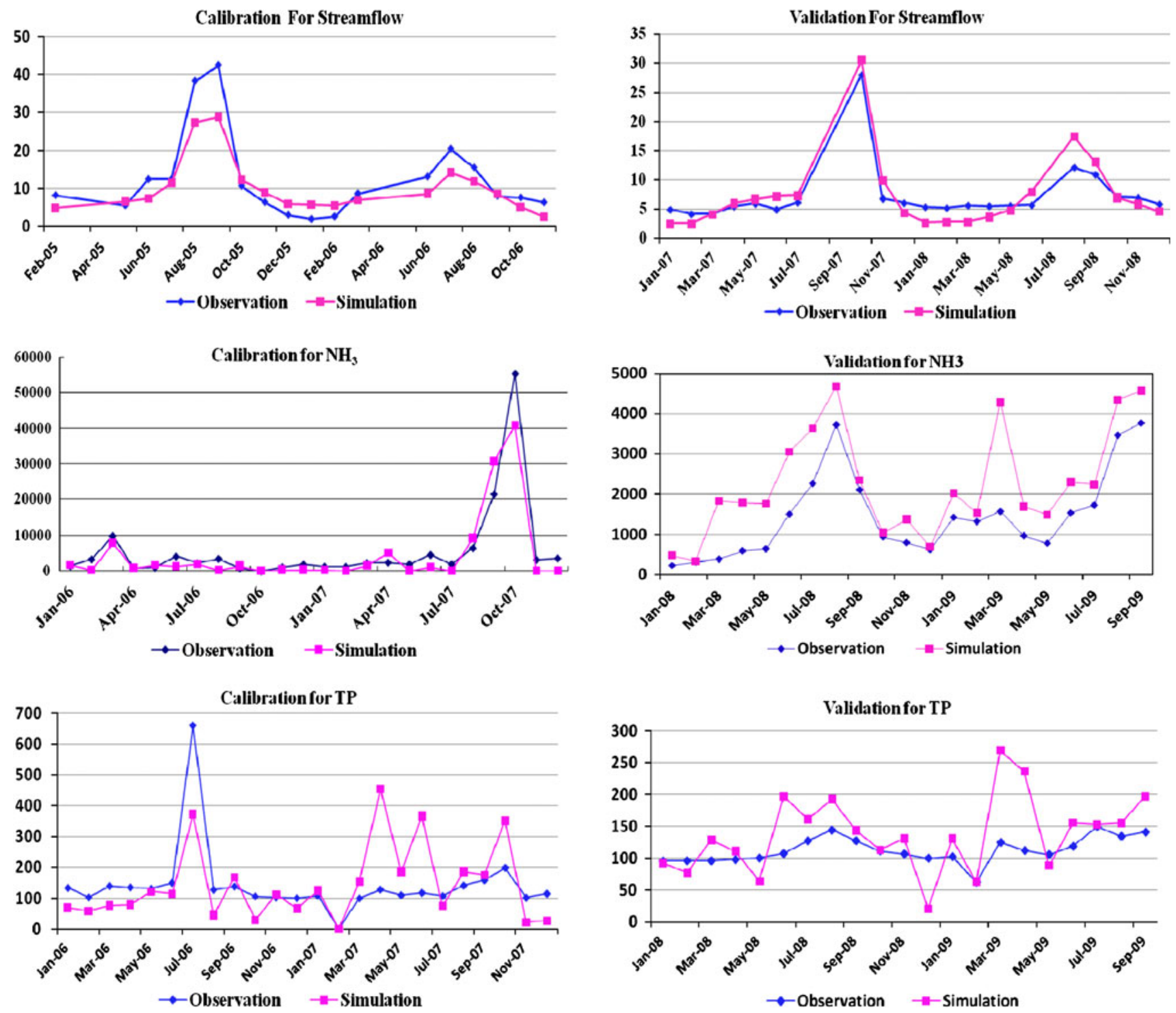

Fig. 4 Calibration and validation results 

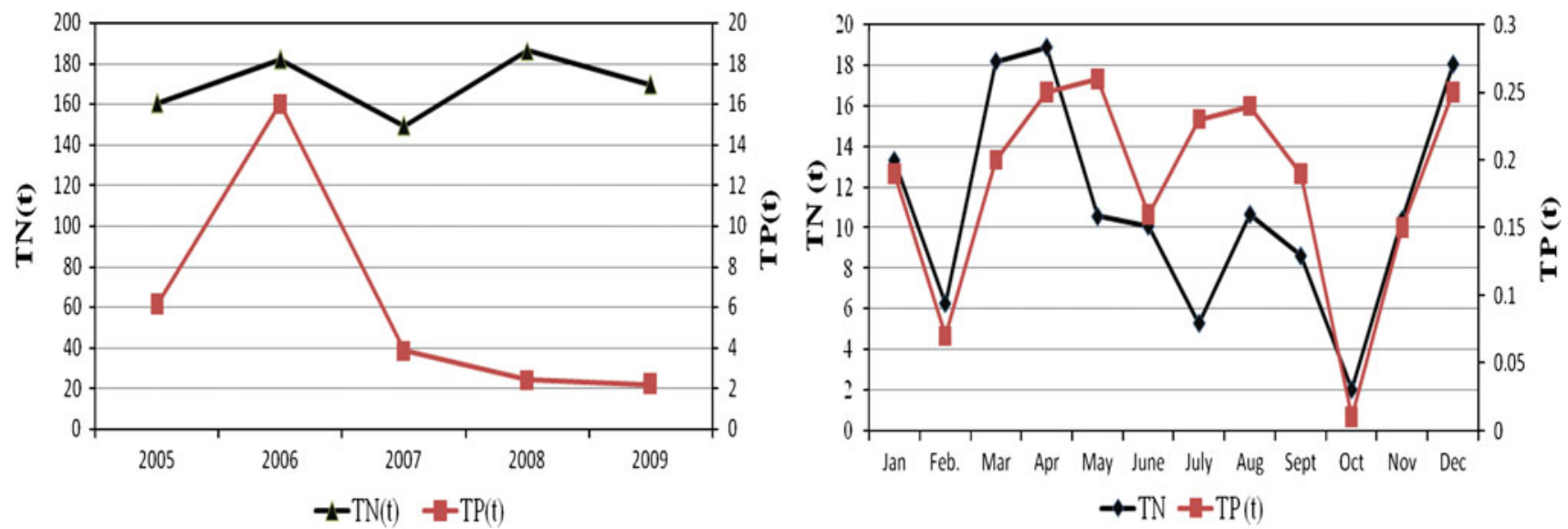

Fig. 5 Temporal distribution of TN and TP

from October onwards due to the degradation of crop residues and leaf fall in the forest areas. These results are similar to those found in Shen et al. (2010), demonstrating that upstream NPS pollution was due to a combination of seasonal precipitation and human activities.

\section{Spatial distribution}

As shown in Fig. 6, rainfall was not uniformly distributed in the Baixi watershed, with the highest rainfall in the east, followed by the west region, and the least rainfall in the central area. The averaged rainfall was $1722 \mathrm{~mm}$. The distribution pattern of runoff was, however, different from that of rainfall because runoff was related to precipitation as well as surface conditions such as slope and soil-water capacity. The averaged runoff was $220 \mathrm{~mm}$, varying from 59 to $410 \mathrm{~mm}$ over the Baixi watershed. TN and TP, were both affected and dominated by the runoff processes. Areas with higher TN load were mainly in farmlands, mountain bush land and low-coverage shrub areas, associated with skeleton soil and yellow soil. The spatial distribution of TP and runoff was similar, mainly because most $\mathrm{P}$ existed as organic P, attached to sediment (Daniel et al. 1998; Shen et al. 2008), and thus, had a positive relationship with soil erosion.

Further studies were conducted by delimiting and summing $\mathrm{N}$ and $\mathrm{P}$ load from Hydrological Response Units (HRU), from which various land uses as well as soil types were analyzed. Results indicated in Table 4 showed that forest land accounted for $91.41 \%$ of organic N, $88.80 \%$ of nitrate $\mathrm{N}$, and $88.56 \%$ of organic $\mathrm{P}$ in the Baixi watershed and cropland exports accounted for $6.67 \%$ of organic N, $9.94 \%$ of nitrate $\mathrm{N}$, and $11.38 \%$ of organic $\mathrm{P}$; while the bare land accounted for $1.92 \%$ of organic N, $1.26 \%$ of nitrate $\mathrm{N}$, and $0.06 \%$ organic $\mathrm{P}$. In some aspects, these results from this study were consistent with those of Chang et al. (2008) and Shen et al. (2010), since forest runoff was shown to contribute a major fraction of NPS pollution. In other respects, however, as described in the studies of Grace (2005) and Stuart and Edwards (2006), forest appeared to export lower sediment yield and had no apparent impact on the receiving water body. This discrepancy could be explained by the studies of Grace (2005) as well as Stuart and Edwards (2006) who focused on undisturbed forest regions. It should, however, be noted that the watersheds described by Chang et al. (2008) and Shen et al. (2010) located in the Tsengwen Reservoir, Taiwan, and the Three Gorges region area, China, in which anthropogenic disturbances, such as cutting and harvesting, occurred. The poor capacity of the forests for water conservation of these areas may have been due to soil compaction and poor ground cover under the trees. In the Baixi watershed, the forestland was constituted of secondary forest and product forest, with low levels of plant residue (Lesschen et al. 2007). In addition, the slope of forestland in the Baixi watershed was higher compared to that in the other two land-use areas, resulting in more rapid runoff.

Skeleton soil and yellow soil accounted for $68.41 \%$ of the total basin, and the percentage of total pollution load that originated from these soils was $70.13 \%$ of organic N, $31.52 \%$ of nitrate $\mathrm{N}$, and $31.39 \%$ of organic $\mathrm{P}$ (Table 5). The relative abundance of organic $\mathrm{N}$ exported from different soil types was as follows: skeleton soil $>$ yellow soil $>$ red-yellow soil $>$ red soil $>$ paddy soil; while that for nitrate $\mathrm{N}$ and organic $\mathrm{P}$ was as follows: yellow soil $>$ skeleton soil $>$ red-yellow soil $>$ red soil $>$ paddy soil; and that for organic nitrogen was: skeleton soil $>$ yellow soil $>$ red-yellow soil $>$ red soil $>$ paddy soil. These results may be explained in terms of the manner in which $\mathrm{N}$ and $\mathrm{P}$ area applied when planting crops, i.e., mainly in the upper $10 \mathrm{~cm}$ of soil (Akhavan et al. 2005). This result in these nutrients either remaining in the soils or being exported to surface waters by erosion or leaching (Shen et al. 2010). 


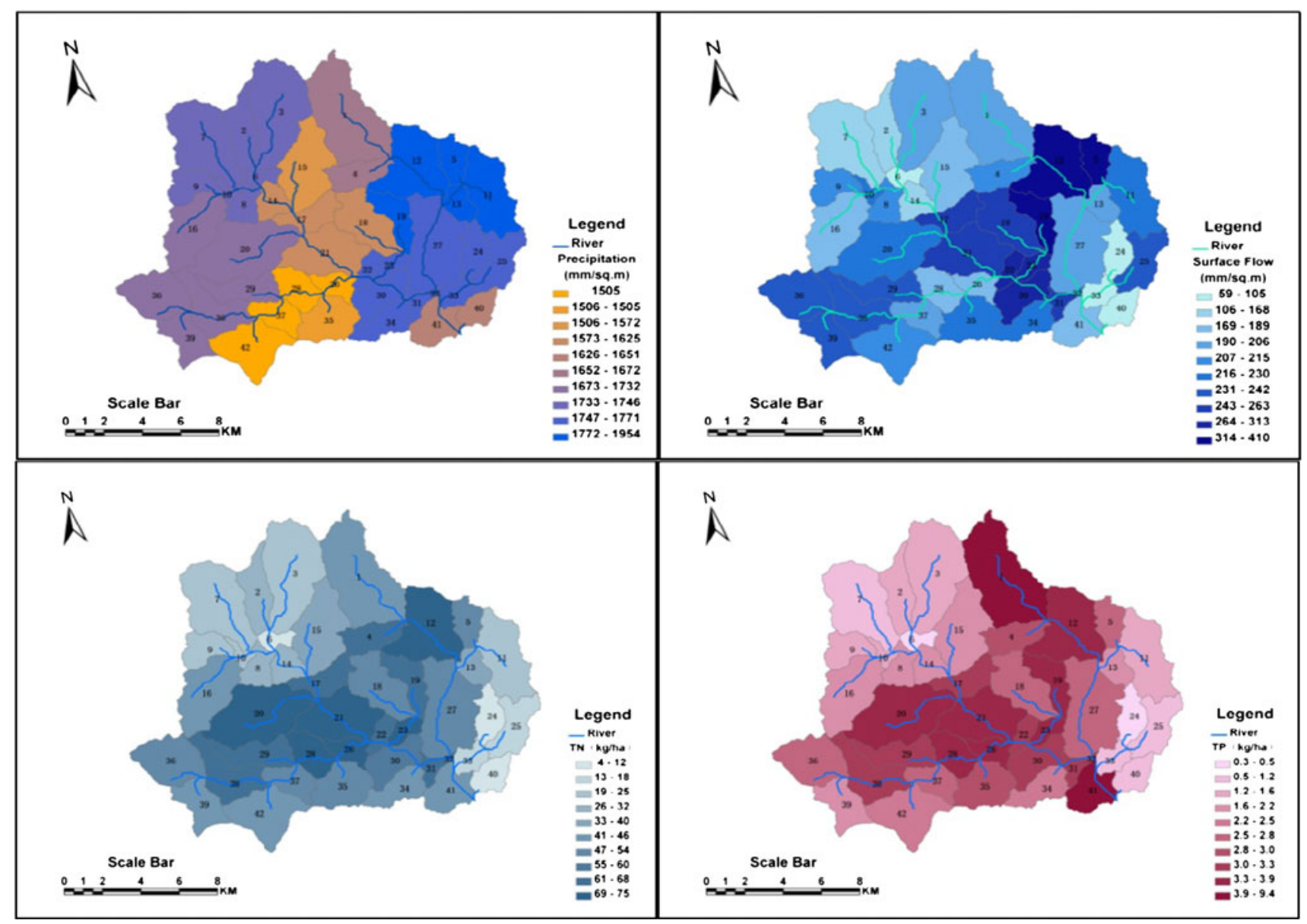

Fig. 6 Spatial distribution of TN and TP

Table $4 \mathrm{~N}$ and $\mathrm{P}$ production in different land use areas

\begin{tabular}{lllll}
\hline Land use & Area $\left(\mathrm{km}^{2}\right)$ & Organic $\mathrm{N}(\mathrm{t})$ & Nitrate $(\mathrm{t})$ & Organic P (t) \\
\hline Forest & 229.81 & 494.77 & 4.15 & 21.48 \\
Paddy & 16.76 & 55.38 & 0.37 & 2.76 \\
Bare land & 4.84 & 7.02 & 0.05 & 0.01 \\
Total & 251.40 & 557.17 & 4.57 & 24.25 \\
\hline
\end{tabular}

Atmospheric deposition load estimation

Rain samples were collected and analyzed during the median rainfall season and the wet season. As could be seen in Table 2, the $\mathrm{pH}$ values measured on these collection dates were from 4.06 to 5.50 , showing obvious characteristics of acid rain (the acid rain was defined as precipitation in which the $\mathrm{pH}$ was less than 5.6). Based on the rain samples from 2005 to 2010, the concentration of TN varied from 0.43 to $2.8 \mathrm{mg} / \mathrm{l}$, with an averaged value of $1.06 \mathrm{mg} / \mathrm{l}$. As there was no obvious difference between median rainfall season and the wet season, so this study regarded $1.06 \mathrm{mg} / \mathrm{l}$ and $0.012 \mathrm{mg} / \mathrm{l}$ as the background concentration of $\mathrm{TN}$ and $\mathrm{TP}$ to represent the acid rain. It
Table 5 The $\mathrm{N}$ and $\mathrm{P}$ production in different soil

\begin{tabular}{lllll}
\hline Soil type & $\begin{array}{l}\text { Area } \\
\left(\mathrm{km}^{2}\right)\end{array}$ & $\begin{array}{l}\text { Organic } \mathrm{N} \\
(\mathrm{t})\end{array}$ & $\begin{array}{l}\text { Nitrate } \\
(\mathrm{t})\end{array}$ & $\begin{array}{l}\text { Organic P } \\
(\mathrm{t})\end{array}$ \\
\hline Skeleton soil & 87.768 & 36.881 & 0.278 & 1.625 \\
Red soil & 30.694 & 2.753 & 0.016 & 0.077 \\
$\begin{array}{l}\text { Red-yellow } \\
\quad \text { soil }\end{array}$ & 48.797 & 5.891 & 0.036 & 0.150 \\
$\quad$ Yellow soil & 83.608 & 39.746 & 0.547 & 2.291 \\
Paddy soil & 0.626 & 0.015 & 0.001 & 0.006 \\
Total & 251.494 & 284.065 & 2.617 & 12.479 \\
\hline
\end{tabular}

was reported that $\mathrm{TN}$ concentration from the Jiulong watershed was in the range of $2.2 \pm 1.69 \mathrm{mg} / \mathrm{l}$ (Chen et al. 2008). Acid rain sampling of $\mathrm{TN}$ in the present study was, however, judged to be lower due to a lower proportion of agriculture land and the less use of fertilizers in the Baixi watershed.

Then TN and TP load due to atmospheric deposition were calculated from the precipitation data from 2005 to 2009. As shown in Fig. 6, TN and TP from atmospheric deposition had similar trends: highest levels in 2007 
(395.39 $\mathrm{t}$ for TN and $3.27 \mathrm{t}$ for TP), followed by 2008 (336.56 t for TN and 2.78 $\mathrm{t}$ for TP) and 2005 (331.35 t for $\mathrm{TN}$ and $2.74 \mathrm{t}$ for TP), while the lowest level was measured in 2006 (287.69 $\mathrm{t}$ for TN and $2.38 \mathrm{t}$ for TP). There was an obvious relationship between atmospheric deposition flux and precipitation amount. The levels of NPS-N and NPS-P in the drinking water reservoir were, however, different to those of the upstream (Fig. 5). The contribution of atmospheric $\mathrm{N}$ input $(36.52 \%$ in $2005,64.01 \%$ in 2006 , $47.91 \%$ in 2007 and $79.30 \%$ in 2008), with an annual averaged contribution of $50.64 \%$ was higher than that of $\mathrm{P}$ (2.12\% in 2005, $7.94 \%$ in 2006, $2.38 \%$ in 2007, and $17.16 \%$ in 2008, with an average of $3.58 \%$ ). This result supported the view that NPS-N was linked to atmospheric acid deposition, while the upstream watershed was the main source of NPS-P (Gunes 2008). However, as described in Chen et al. (2008), atmospheric $\mathrm{N}$ deposition accounted for only $30 \%$ of total $\mathrm{N}$ input into the receiving water body. This discrepancy could be due to the watershed studied by Chen et al. (2008) located in the Anhui province, where agricultural land is the most significant anthropogenic source of NPS pollution. It can be further explained that although cropland has a higher NPS-N concentration per area $(7.91 \mathrm{~kg} / \mathrm{ha}$ for Nitrate $\mathrm{N})$ compared to the forest lands $(6.39 \mathrm{~kg} / \mathrm{ha}$ for Nitrate $\mathrm{N})$, forested areas make up $91 \%$ of the land-use area (Table 4), resulting in a lower upstream $\mathrm{N}$ input than that of Chen et al. (2008). According to EPA (1999), the $\mathrm{N}$ concentration of the rainfall (both normal rain and acid rain) in USA was $0.9 \mathrm{mg} / \mathrm{l}$, whereas the $\mathrm{P}$ concentration was $0.015 \mathrm{mg} / \mathrm{l}$. Thus, it can be inferred that atmospheric $\mathrm{N}$ deposition might be the main NPS-N source in the acid rain-control region, while acid rain had little effect on the NPS-P amount.

In this study, monthly $\mathrm{N}$ and $\mathrm{P}$ were further analyzed (Fig. 7). The main source of NPS-N and NPS-P was linked to the rainy period. The peak values of TN and TP both occurred in June (30.70 $t$ for TN and $0.08 \mathrm{t}$ for TP) and
July (31.18 $\mathrm{t}$ for TN and $0.09 \mathrm{t}$ for TP), when rainfall was frequent and intense. Atmospheric deposition load was high in May (16.18 t TN; 0.04 t TP), August (17.69 t TN; $0.05 \mathrm{t}$ TP) and September (18.94 t TN; $0.05 \mathrm{t}$ TP), while December contributed the least load $(0.22 \mathrm{t} \mathrm{TN}$ and $0.01 \mathrm{t}$ TP). Compared to upstream regions (Fig. 5), however, atmospheric deposition was the main source of NPS-N from June to September (mainly in rainy months, $87.16 \%$ in September), while upper watershed had higher contributions in February (74.57 \%) and December (91.25 \%). In other months, there was very little difference of the contributions between atmospheric deposition and upstream flow. Previous studies were traditionally based on the assumption that NPS input was mainly from overland flow, which also accounted for impaired drinking water (Livingst and Cory 1998; Ghaffari et al. 2010). This research, however, challenged this assumption, noting that atmospheric $\mathrm{N}$ deposition via acid rain might be the main source of pollution in the acid rain-control region, particularly during the rainy season. As a comparison, upstream watershed was the main source of NPS-P for most of the year, except during February and September. This study therefore suggests that NPS-N and NPS-P pollution may originate from diverse sources; thus, the distinct identification and management of NPS-N and NPS-P should be taken in such areas.

\section{Rural and tourism load estimation}

To further identify the origins of upstream pollution, NPS$\mathrm{N}$ and NPS-P from rural and tourism were estimated based on the investigation of rural human population, and poultry data in 2009 and 2010. Based on the ECM theory, 0.7 was chosen as the coefficient for sanitary sewage, while that organic waste and excrement was estimated to be 0.35 for $\mathrm{TN}$ and 0.05 for TP. The coefficient for tourism pollution was chosen as 0.9. All these coefficients were the most frequently used in watershed modeling in the Baixi
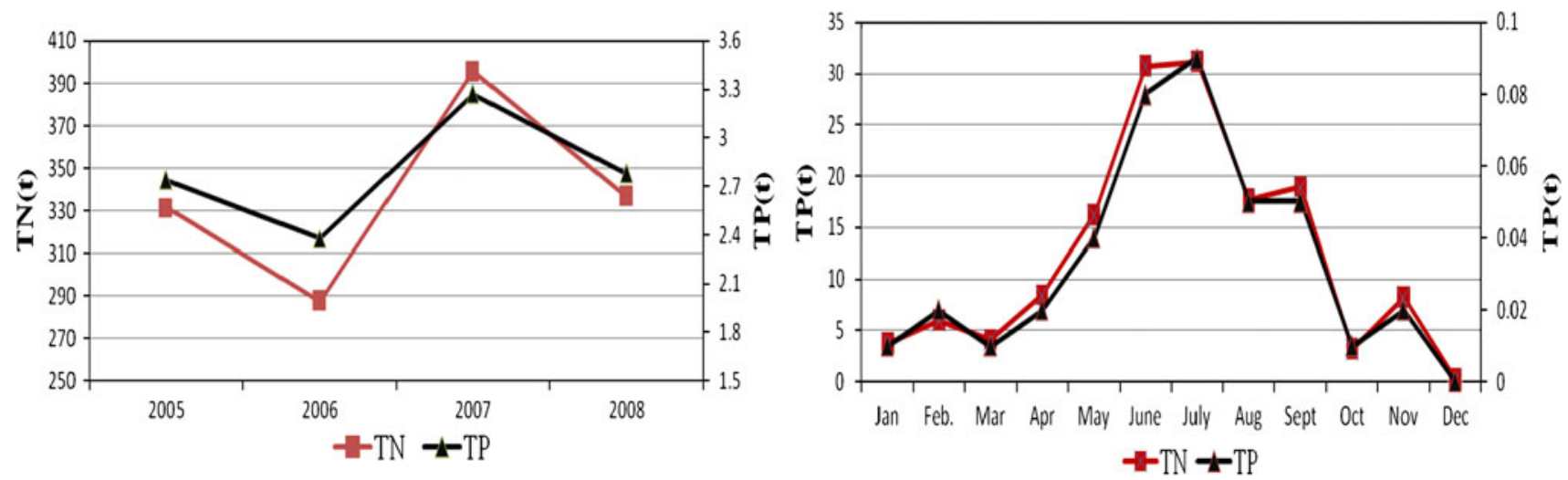

Fig. 7 Temporal distribution of atmospheric deposition flux 
watershed. As shown in Tables 6 and 7, the amount from annual rural pollution was $71.74 \mathrm{t}$ for $\mathrm{TN}$ and $11.17 \mathrm{t}$ for $\mathrm{TP}$, while tourism made up $0.042 \mathrm{t}$ for TN and $0.016 \mathrm{t}$ for TP. Our results supported previous findings that rural and livestock pollution might be an important source of TP in runoff (Sharpley et al. 2003; Bilotta et al. 2008).

\section{Comparison of NPS sources}

As described in Fig. 8, atmospheric deposition was the major source of NPS-N, accounting for almost more than a half of the annual $\mathrm{TN}$ into the drinking water reservoir $(56.74 \%)$. In upstream flow, the contribution from forested and rural areas was 27.72 and $12.05 \%$, respectively. Other sources such as tourism $(0.39 \%)$, paddy fields $(2.46 \%)$ and bare land $(0.62 \%)$, contributed less to the total amount of NPS-N. With respect to NPS-P pollution, the forested area was identified as the most significant source (i.e., $58.78 \%$ ); with the contribution from rural pollution being $25.08 \%$, followed by atmospheric deposition (6.27\%), paddy field (7.32\%), tourism $(2.09 \%)$ and bare land $(0.67 \%)$. Based on this evaluation, it was concluded that in acid rain-control areas, NPS-N and NPS-P in drinking water reservoirs often derived from extensive sources such as land-use, rural populations, the livestock industry and atmospheric deposition. The main cause of eutrophication due to NPS-N could be due to the increased input of atmospheric acid deposition. Upstream NPS-N typically increased substantially after harvesting and fertilization, while maximum $P$ could be linked to overland runoff from forest fields and other anthropogenic sources such as rural and livestock pollution. The control of NPS-P should center on land-use and rural management, while NPS-N management should be based on a combination of land practices management and the control of the pollutants release into the atmosphere. It can be further inferred that due to global $\mathrm{N}$ cycling and greenhouse gas NOX emissions, the NPS-N from atmospheric acid deposition and upper watershed might cause a wide range of problems to

Table 6 Rural pollution in Baixi watershed

\begin{tabular}{llllll}
\hline Source & \multicolumn{2}{l}{ Chalu town } & & \multicolumn{2}{l}{ Huangtan town } \\
\cline { 2 - 3 } & TN $(\mathrm{t})$ & $\mathrm{TP}(\mathrm{t})$ & & $\mathrm{TN}(\mathrm{t})$ & $\mathrm{TP}(\mathrm{t})$ \\
\hline Sanitary sewage & 1.09 & 0.22 & & 1.39 & 0.28 \\
Pig excrement & 2.15 & 0.24 & & 1.88 & 0.21 \\
Cow excrement & 7.25 & 0.73 & & 17.02 & 1.70 \\
Sheep excrement & 0.21 & 0.02 & & 1.07 & 0.11 \\
Domesticated fowl excrement & 0.63 & 0.13 & & 0.81 & 0.16 \\
Organic trash & 15.28 & 3.06 & & 19.49 & 3.90 \\
Person excrement & 1.53 & 0.19 & & 1.95 & 0.24 \\
Total & 28.13 & 4.57 & & 43.61 & 6.60 \\
\hline
\end{tabular}

Table 7 Tourism pollution in Baixi watershed

\begin{tabular}{lll}
\hline Month & TN $(\mathrm{kg})$ & TP $(\mathrm{kg})$ \\
\hline 1 & 0.94 & 0.38 \\
2 & 1.31 & 0.53 \\
3 & 2.72 & 1.09 \\
4 & 3.91 & 1.57 \\
5 & 7.42 & 2.97 \\
6 & 3.15 & 1.26 \\
7 & 4.21 & 1.68 \\
8 & 4.84 & 1.94 \\
9 & 2.54 & 1.02 \\
10 & 7.23 & 2.89 \\
11 & 2.82 & 1.13 \\
12 & 1.26 & 0.50 \\
Sum & 42.35 & 16.94 \\
\hline
\end{tabular}

drinking water resources such as eutrophication, oxygen depletion, and loss of biodiversity (Holland et al. 1999; Nadelhoffer 2001). Thus, the measurement and regulation of NPS-N in acid rain-control regions present a significant challenge.

The sources of NPS pollution appeared to show the temporal variability in terms of monthly NPS-N and NPS-P (Fig. 9). Atmosphere deposition was judged the main source of NPS-N during the high rainfall season, mainly from June to August. During February, March and October, the contribution of NPS-N from forestlands was higher than that from atmosphere deposition. The levels of NPS-N pollution from these two different sources were similar during other months, while rural and livestock pollution was other important source of NPS-N in November and December. To achieve effective management and control of NPS-N, it is thus important to focus attention on the period of heavy acid precipitation in the drinking water region, and particularly during periods of heavy precipitation. Forested areas were the main source of NPS-P throughout the year in the Baixi watershed, so management was required to focus on these areas from the upper watershed.

It can be further inferred that the regional assessment of NPS-N in such an acid rain-control region might be more complicated than would be the case for NPS-P, which was spatially and temporally distributed throughout the upper watershed. Thus, the corresponding framework for NPS-N identification should combine the knowledge and techniques to accurately identify the diverse sources of NPS-N. In this paper, it was found that the most reliable results could be obtained by combining a amount of methods and techniques, making use of a watershed model, a simple ECM, rain sampling and a GIS-based tool to assess NPS-N load, both spatially and temporally. This combination 

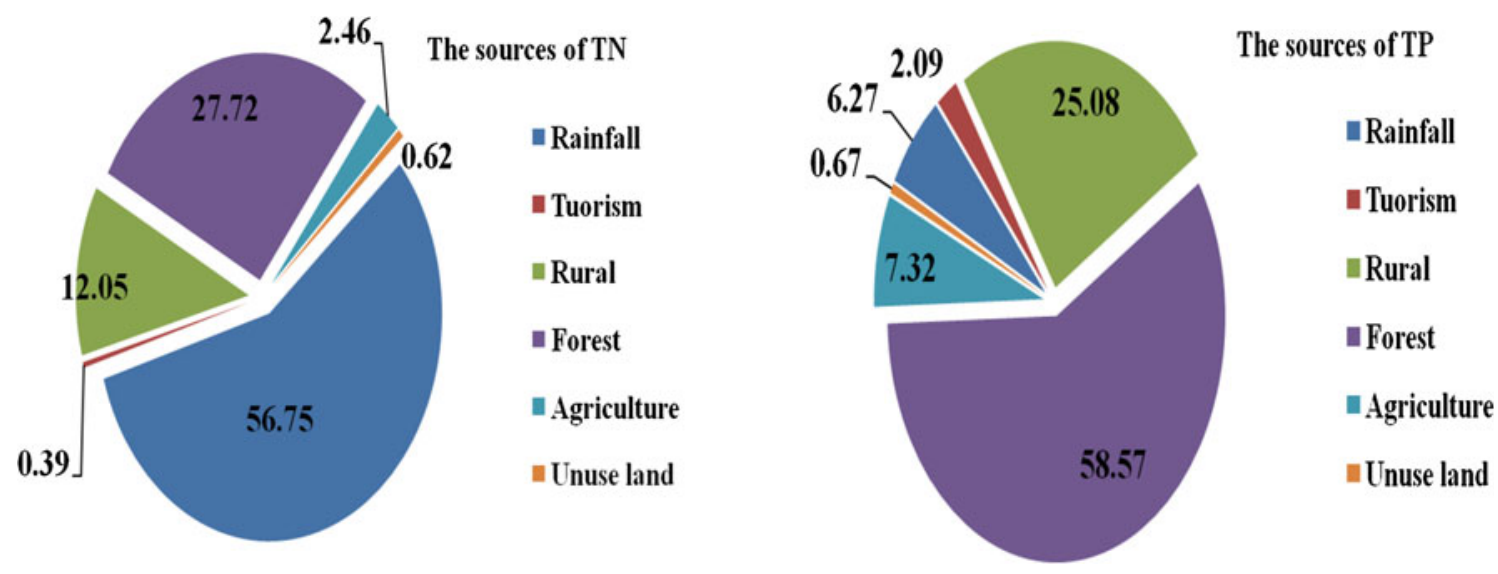

Fig. 8 The sources of annual TN and TP

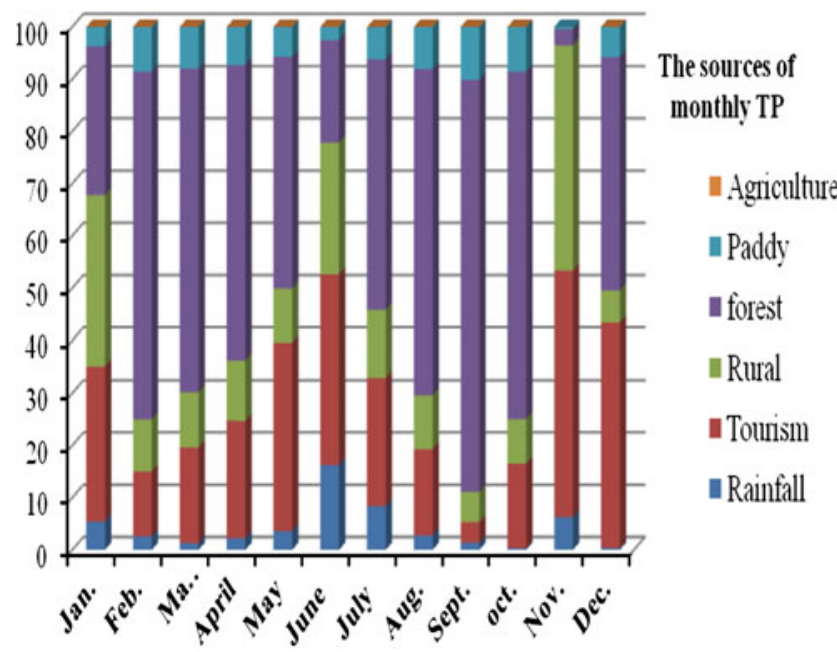

Fig. 9 The sources of monthly TN and TP

framework could be helpful in providing detailed and dynamic information for water quality management in similar regions.

\section{Conclusion}

In this study, an integrated simulation-monitoring framework was applied to estimate the spatial and temporal distribution of NPS-N and NPS-P in a typical acid raincontrol drinking water reservoir that supplied the city of Ningbo, Zhejiang Province, China. Based on this study, atmospheric deposition accounted for the highest proportion of NPS-N load through acid rainfall. Maximum NPS-P was linked to overland flow, originating from land-use practices in the upstream watershed. It was inferred that atmospheric deposition could be a progressive threat to aquatic health in the similar acid rain-influenced regions and NPS-N management should be based on a combination

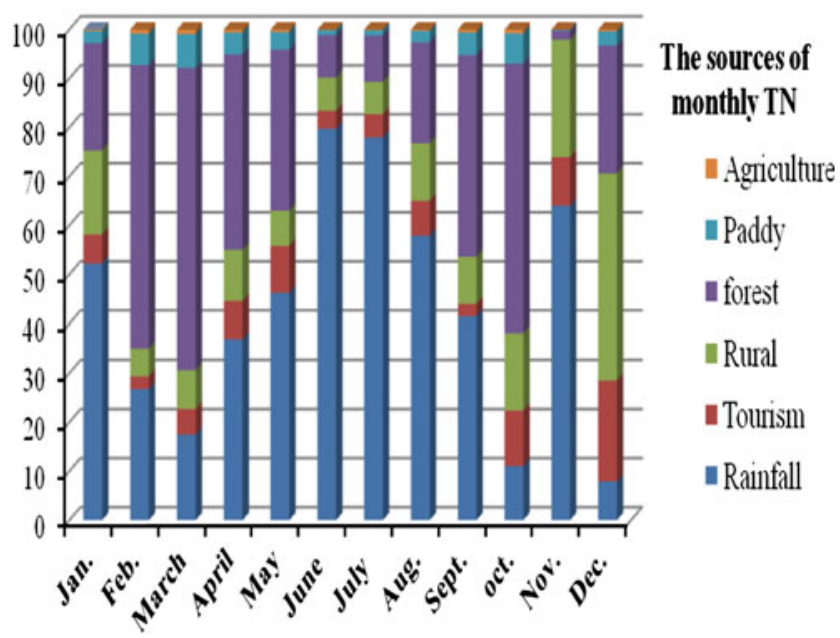

of land-use management and the control of pollutant release to the atmosphere in acid rain-control drinking water areas. The results and corresponding methods could provide a helpful foundation for taking a sound action to improve water quality management in such regions.

Acknowledgments The study was supported by National Science Foundation for Distinguished Young Scholars (No. 51025933), Program for Changjiang Scholars and Innovative Research Team in University (No. IRT0809), and the National Natural Science Foundation of China (Grant No. 41001352).

\section{References}

Abbott MB, Bathhurst JC, Cunge JA (1986) An introduction to the European hydrological system-systeme hydrologique Europeen, "SHE", 2: structure of a physically-based distributed modeling system. J Hydrol 87(1-2):61-77

Akhavan S, Mazaheri A, Saggadian V, Noohi A (2005) Production of biosurfactant from Iranian oil fields by isolated Bacilli. Int $\mathbf{J}$ Environ Sci Tech 1(4):287-293 
Arnold JG, Allen PM, Bernhardt G (1993) A comprehensive surfacegroundwater flow model. J Hydrol 142(1-4):47-69

Beasley DB, Huggins LF, Monke EJ (1980) ANSWERS: a model for watershed planning. Tran ASAE 23(4):938-944

Behera S, Panda RK (2006) Evaluation of management alternatives for an agricultural watershed in a sub-humid subtropical region using a physical process based model. Agric Ecosyst Environ 113(1-4):62-72

Bicknell BR, Imhoff JC, Jobes TH, Kittle JLJ, Donigian ASJ (2001) Hydrological Simulation Program-Fortran (HSPF Version 12): user's manual. U.S. Environmental Protection Agency, Washington, DC, pp 101-140

Bilotta GS, Brazier RE, Haygarth PM, Macleod CJA, Butler P, Ganger S (2008) Rethinking the contribution of drained and undrained grasslands to sediment-related water quality problems. J Environ Qual 37(3):906-914

Birr A (2001) Evaluation of the phosphorus index in watersheds at the regional scale. J Environ Qual 30(6):2018-2025

Bowes MJ, Hilton J, Irons GP, Hornby DD (2005) The relative contribution of sewage and diffuse phosphorus sources in the River Avon catchment, southern England: implications for nutrient management. Sci Total Environ 344(1-3):67-81

Canale RP, Effler SW (1989) Stochastic phosphorous model for Onondaga Lake. Water Res 23(8):1009-1016

Carey BM (2002). Effects of land application of manure on ground water at two dairies over the Sumas-Blaine surficial aquifer. Washington Department of Ecology, Publication No. 02-03-007. 541-590

Chang CH, Wen CG, Huang CH, Chang SP, Lee S (2008) Nonpoint source pollution loading from an undistributed tropic forest area. Environ Monit Assess 146(1-3):113-126

Chaubey I, Haan CT, Grunwald S, Salisbury JM (1999) Uncertainty in the model parameters due to spatial variability of rainfall. J Hydrol 220(1-2):48-61

Chen NW, Hong HS, Zhang LP (2008) Wet deposition of atmospheric nitrogen in Jiulong river watershed. Huanjing Kexue 29(1): $38-48$

Chen M, Chen J, Sun F (2010) Estimating nutrient releases from agriculture in China: an extended substance flow analysis framework and a modeling tool. Sci Total Environ 408(21): 5123-5136

Cho J, Park S, Im S (2008) Evaluation of agricultural nonpoint source (AGNPS) model for small watersheds in Korea applying irregular cell delineation. Agric Water Manage 95(4):400-408

Daniel TC, Sharpley AN, Lemunyon JL (1998) Agricultural phosphorus and eutrophication: a symposium overview. J Environ Qual 27:251-257

Ding XW, Shen ZY, Hong Q, Yang ZF, Wu X, Liu RM (2010) Development and test of the export coefficient model in the upper reach of the Yangtze river. J Hydrol 383(3-4):233-244

Edwards AC, Withers PJA (2008) Transport and delivery of suspended solids, nitrogen and phosphorus from various sources to freshwaters in the UK. J Hydrol 350(3-4):144-153

Ernst MR, Owens J (2009) Development and application of a WASP model on a large Texas reservoir to assess eutrophication control. Lake Reser Manage 25(2):136-148

Esen E, Uslu O (2008) Assessment of the effects of agricultural practices on non-point source pollution for a coastal watershed: a case study Nif Watershed, Turkey. Ocean Coast Manage 51(12):601-611

Francos A, Elorza FJ, Bouraou F, Bidoglio G, Galbiat L (2003) Sensitivity analysis of distributed environmental simulation models, understanding the model behaviour in hydrological studies at the catchment scale. Reliab Eng Sys Safe 79(3):205-218
Gassman P, Reyes M, Green C, Arnold J (2007) The soil and water assessment tool, historical development, applications, and future research directions. Tran ASAE 50(4):1211-1250

Gburek WJ, Sharpley AN, Heathwaite L, Folmar GJ (2000) Phosphorus management at the watershed scale, a modification of the Phosphorus Index. J Environ Qual 29(1):130-144

Ghaffari G, Keesstra S, Ghodousi J, Ahmad H (2010) SWATsimulated hydrological impact of land-use change in the Zanjanrood Basin, Northwest Iran. Hydro Process 24(7):892-903

Grace JM (2005) Forest operations and water quality in the South. Trans ASAE 48(2):871-880

Gunes K (2008) Point and nonpoint sources of nutrients to lakesecotechnological measures and mitigation methodologies-case study. Ecol Eng 34(2):116-126

Hallberg GR, Keeney DR (1993) Nitrate. In: Alley WM (ed) Regional ground-water quality. U.S. Geological Survey, Van Nostrand Reinhold, New York, pp 297-321

Harter T, Davis H, Mathews M, Meyer R (2002) Shallow groundwater quality on dairy farms with irrigated forage crops. J Contam Hydrol 55(3-4):287-315

Holland EA, Dentener FJ, Braswell BH, Sulzman JM (1999) Contemporary and preindustrial global reactive nitrogen budgets. Biogeochemistry 46(1-3):7-43

Huang DY, Xu YG, Zhou B, Zhang HH, Lan JB (2010) Wet deposition of nitrogen and sulfur in Guangzhou, a subtropical area in South China. Environ Monit Assess 171(1-4):429-439

Hubbard RK, Sheridan JM (1994) Nitrates in Groundwater in the Southeastern USA. In: Adriano DC, Iskandar AK, Murarka IP (eds) Contamination of groundwaters. Science Reviews, Northwood, pp 303-345

Igbinosa EO, Okoh AI (2009) Impact of discharge wastewater effluents on the physico-chemical qualities of a receiving watershed in a typical rural community. Int J Environ Sci Tech 6(2):175-182

Jiang Y, Jin LS, Lin T (2011) Higher water tariffs for less river pollution-evidence from the Min River and Fuzhou City in China. China Eco Rev 22(2):183-195

Johnes PJ (1996) Evaluation and management of the impact of land use change on the nitrogen and phosphorus load delivered to surface waters, the export coefficient modelling approach. J Hydrol 183(5):323-349

Jury W, Nielsen D (1989) Nitrate transport and leaching mechanics. In: Follett RF (ed) N management and ground water protection. Elsevier, Amsterdam, pp 139-157

Karbassi R, Torabi F, Ghazban F, Ardestani M (2011) Association of trace metals with various sedimentary phases in dam reservoirs. Int J Environ Sci Tech 8(4):841-852

Kho FWL, Law PL, Lai SH, Oon YW, Ngu LH, Ting HS (2009) Quantitative dam break analysis on a reservoir earth dam. Int $\mathbf{J}$ Environ Sci Tech 6(2):203-210

Lemunyon JL, Gilbert RG (1993) The concept and need for a phosphorus assessment tool. J Prod Agric 6:483-486

Lesschen JP, Stoorvogel JJ, Smaling EMA, Heuvelink GBM, Veldkamp A (2007) A spatially explicit methodology to quantify soil nutrient balances and their uncertainties at the national level. Cycl Agroecosyst 78(2):111-131

Li SQ, Li SX (1999) Nitrogen added to ecosystems by wet deposition in Guanzhong area in Shaanxi. Agro Environ Prot 18(3):97-101

Ling G, El-Kadi A (1998) A lumped parameter model for $\mathrm{N}$ transformation in the unsaturated zone. Water Resour Res 34(2):203-212

Livingston ML, Cory DC (1998) Agricultural nitrate contamination of ground water, an evaluation of environmental policy. J Am Water Resour Assoc 34(6):1311-1317 
Magette WL (1993) Factors affecting losses of nutrients from agricultural systems and delivery to water resources. Teagasc, Johnstown Castle Research Centre, Wexford, pp 54-90

Markus M, Hejazi MI, Bajcsy P, Giustolisi O, Savic DA (2010) Prediction of weekly nitrate-N fluctuations in a small agricultural watershed in Illinois. J Hydroform 12(3):251-261

Meng X (2009) In: Lin T, Swanson T (eds) Economic growth and environmental regulation, The PRC's path to a brighter future, pp 56-65

Nadelhoffer KJ (2001) The impacts of nitrogen deposition on forest ecosystems. In: Follett RF, Hatfield JL (eds) Nitrogen in the environment, sources, problems, and management. Elsevier, Amsterdam, pp 311-331

Nandakumar N, Mein RG (1997) Uncertainty in rainfall-runoff model simulations and the implications for predicting the hydrologic effects of land-use change. J Hydrol 192(1-4):211-232

Nash JE, Sutcliffe JV (1970) River flow forecasting through conceptual models. Part I-a discussion of principles. J Hydrol 10(3):282-290

Omernik JM (1976) The influence of land use on stream nutrient levels. U.S. Environmental Protection Agency, Washington, DC, pp 78-90

Paul JW, Zebarth BJ (1997) Denitrification and nitrate leaching during the fall and winter following dairy cattle slurry application. Can J Soil Sci 77(2):231-240

Petersen GW, Hamlett JM, Baumer GM, Miller DA, Day RL (1991) Evaluation of agricultural nonpoint pollution potential in Pennsylvania using a Geographic Information System. Pennsylvania Department of Environmental Resources, Harrisburg, pp 45-67

Plus M, Jeunesse IL, Bouraoui F, Zaldívar JM, Chapelle A, Lazure P (2006) Modelling water discharges and nitrogen inputs into a Mediterranean lagoon impact on the primary production. Ecol Model 193(1-2):69-89

Ribarova I, Ninov P, Cooper D (2008) Modeling nutrient pollution during a first flood event using HSPF software, Iskar River case study, Bulgaria. Eco Model 211(1-2):241-246

Santhi C, Srinivasan R, Arnold JG, Williams JR (2006) A modeling approach to evaluate the impacts of water quality management plans implemented in a watershed in Texas. Environ Model Softw 21(8):1141-1157

Sharpley AN, Daniel T, Sims T, Lemunyon J, Stevensk R, Parry R (2003) Agricultural phosphorus and eutrophication, 2nd edn ( $p$ 44). U.S. Department of Agriculture, Agricultural Research Service, Washington, DC, Publication no. ARS-149, pp 1-30

Shen ZY, Hong Q, Yu H (2008) Parameter uncertainty analysis of the non-point source pollution in the Daning River watershed of the
Three Gorges Reservoir Region, China. Sci Total Environ 405(1-3):195-205

Shen ZY, Hong Q, Yu H (2010) Parameter uncertainty analysis of non-point source pollution from different land use types. Sci Total Environ 408(8):1971-1978

Singh VP, Frevert DK (2002) Mathematical models of large watershed hydrology. Water Resources Publications, LLC, Highlands Ranch, pp 54-68

Singh J, Knapp HV, Arnold JG, Demissie M (2005) Hydrological modeling of the Iroquois River watershed using HSPF and SWAT. J Am Water Resour Assoc 41(2):343-360

Singh R, Tiwari KN, Mal BC (2006) Hydrological studies for small watershed in India using the ANSWERS model. J Hydrol 318(1-4):184-199

Stuart GW, Edwards PJ (2006) Concepts about forests and water. North J Appl Forest 23(1):11-19

Todd DA, Bedient PB, Haasbeek JF, Noel J (1989) Impact of land use and NPS loads on lake quality. J Environ Eng 115(3):633-649

Trauth R, Xanthopoulos C (1997) Non-point pollution of groundwater in urban areas. Water Res 31(11):2711-2718

Tu J, Xia ZG (2008) Examining spatially varying relationships between land use and water quality using geographically weighted regression I, Model design and evaluation. Sci Total Environ 407(1):358-378

USEPA (U.S. Environmental Protection Agency) (2002) Drinking Water Regulations and Health Advisories. EPA 822-R-02-038, Office of Water, Washington, DC

USEPA (U.S. Environmental Protection Agency) (2006) Solving environmental problems through partnership, a case study. New York City Watershed Partnership. Washington DC

Weber A, Fohrer N, Möller D (2001) Long-term land use changes in a mesoscale watershed due to socio-economic factors-effects on landscape structures and functions. Ecol Model 140(1-2):125-140

Whittemore RC (1998) The BASINS model. Water Environ Tech 10:57-61

Williams JR, Nicks AD, Arnold JG (1985) Simulator for water resources in rural basins. J Hydraul Eng ASCE. 111(6):970-986

World Bank (2009) Addressing China's water scarcity, Recommendations for selected water resource management issues. Washington DC, pp 57-69

Yang J, Reichert P, Abbaspour KC, Yang H (2007) Hydrological modelling of the Chaohe basin in china, Statistical model formulation and Bayesian inference. J Hydrol 340(3-4):167-182

Young RA, Onstad CA, Bosch DD, Anderson WP (1989) AGNPS, a nonpoint-source pollution model for evaluating agricultural watersheds. J Soil Water Conserv 44(2):168-173 